\title{
Child sexual abuse and its consequences on mental health: a review of the literature
}

\author{
Camilla Patrícia de Souza ${ }^{1}$; Ellen Lívia de Souza ${ }^{2 *}$; Larissa Emanuelle Correia Silva ${ }^{3}$; Layonara \\ Souza da Silva ${ }^{4}$; Silvia Daiane de Santana Lira ${ }^{5}$; Pierre Teodosio Felix ${ }^{6}$
}

1-5 Psychology Students at University Center of Vitória de Santo Antão (UNIVISA), Vitória de Santo Antão, Pernambuco, Brazil

6 Professor of Psychology Course at University Center of Vitória de Santo Antão (UNIVISA), Vitória de Santo Antão, Pernambuco, Brazil

E-mail adresses: camila.202114088@univisa.edu.br (Camilla Patrícia de Souza), ellen.202114053@univisa.edu.br (Ellen Lívia de Souza), larissa.202114233@univisa.edu.br (Larissa Emanuelle Correia Silva), layonara.202118045@univisa.edu.br (Layonara Souza da Silva), silvia.202114121@univisa.edu.br (Silvia Daiane de Santana Lira),pierrefelix@univisa.edu.br (Pierre Teodosio Felix)

*Corresponding author

\section{To cite this article:}

Souza, C.P.; Souza, E.L.; Silva, L.E.C.; Silva, L.S.; Lira. S.D.S.; Felix, P.T. Child sexual abuse and its consequences on mental health: a review of the literature. International Journal of Sciences. Vol. 2, No. 3, 2021, pp.105-108. ISSN 2763-5392.

Received: 10 25, 2021; Accepted: 10 26, 2021; Published: 11 03, 2021

\begin{abstract}
Notifications of cases of sexual violence against children and adolescents are common throughout Brazil and these notifications are always accompanied by high degrees of neglect and physical and psychological violence. The consequences of this violence indicated in the literature are numerous, the most common being for both sexes: anxiety, anger, dissociation, interpersonal problems, in addition to psychopathologies such as alcohol and substance abuse, depression, eating disorders, obsessive compulsive disorder, posttraumatic stress disorder and borderline personality disorder. The social protection of these children is the most effective modality and care of protection, since it aims at the restructuring of the family group and the elaboration of new moral and affective references. Victims of sexual violence should have their rights guaranteed and the best treatment of the health system, since they may present psychopathological conditions or require psychosocial follow-up and/or psychotherapeutic treatment whenever necessary. In this context, in the present study, data was collected from bibliographic surveys of numerous national and international authors in several databases.
\end{abstract}

Keywords: Child Sexual Abuse. Personality Formation. PTSD. ASI.

\section{Introduction}

Child sexual abuse, also classified as (ASI), is considered, by most specialists, as a traumatic event due to the various emotional, behavioral, social and cognitive sequelae left in its victims, with a range of references in the literature pointing to numerous risk factors associated with its occurrence. (Borges and Dell'Aglio, 2008). Among these factors, issues such as prematurity at birth, low educational level of parents, a greater number of children, separated parents, coercive disciplinary practices, "isolated" families, a poor social support network and the presence of alcoholism and abuse of other drugs stand out among all others (Flores and Caminha, 1994; Koller and De Antoni, 2004). Thus, it is easy to realize that evaluating all possible emotional and behavioral changes becomes a more than important element in the identification of victims (Briere and Elliott, 2003; MacMillan et al., 2001; Tyler, 2002).
Several clinical symptoms clearly point to a constant number of emotional, behavioral and cognitive sequelae in victims of ASI and among the pathologies most associated with the occurrence, although ASI is associated with multiple consequences for child development highlight in mood disorders, anxiety disorders, dissociative disorders, attention deficit disorder (Elliott and Carnes, 2001; Jonzon and Lindblad, 2004). The interaction of all these factors should always be considered as a central aspect in the processes of resilience or a positive adaptation within a context as adverse as this (Luthar et al., 2000).

Intrafamily violence against children and adolescents is a historical practice in Brazilian society, present in all social segments. (Venturini et al., 2004), when examining the literature on intrafamily violence, show that researchers have emphasized that it is the expression of the abuse of power of 
parents or guardians, who "turn children and teenagers into things", making them objects and disrespecting their fundamental rights. This issue denounces the ineffectiveness of the role of family relationships, because the adult, who should exercise the role of protection and care does not, creating a rupture in the protective and identification function, leaving the child in a situation of total helpless (Cromberg, 2001; Mees, 2001; Faiman, 2004; Dos Santos, 2007; Brandão Júnior e Ramos, 2010).

Given this panorama, the abuse and exploitation of children end up becoming a growing field of interests, as their directions are directly linked to political, economic and social processes, on an international scale and denouncing this type of violence becomes an essential task, since silence forgives the aggressor and strengthens his power over the victim (Blanchard, 1996), causing child abuse to become a medicalsocial disease that assumes epidemic proportions and becomes increasingly entrenched in the population (Kaplan and Sadock, 1990).

Thus, this review intends to bring light to questions about the ASI in order to help in the training of the various professionals involved, from a multidisciplinary point of view, highlighting, among them, the psychologists aiming at a better professional performance and an improvement in the quality of therapeutic interventions.

\section{Methodology}

This is a study with data collection based on bibliographic data collection. For this survey, articles were retrieved in several databases such as the Virtual Health Library (VHL), Revista Médica de Minas Gerais (RMMG), PubMed, Biblioteca Virtual em Saúde-Psicologia (PePSIC), American Psychological Association (APA) and Scientific Electronic Library Online (SciELO). The inclusion criteria determined for the selection of articles were: texts available in full, articles in Portuguese and In English from 1984 to 2012 master's dissertations and doctoral theses and articles in full that portray child sexual abuse. All opinions or unreferenced texts served as exclusion criteria in this study.

\section{Results and Discussion}

Sexual assaults against children have always existed in most civilizations. However, before the 1950s, sexuality was generally considered taboo and there was little research on this topic (Blanchard, 1996). In present times, the situation of sexual abuse in childhood has received increasing attention from both the media and the academic environment (Kristensen, 1996) and some authors even suggest that the real frequency of abuse has remained constant over time (Flores and Caminha, 1994; Finkelhor, 1994).

Studies have shown that the relationships established in these aggressions are always composed of an adult in a position of authority and a child who, due his or her stage of development, is unable to understand the nature of closer contacts (Blanchard 1996).

Several authors argue that definitions of sexual abuse commonly imply differences in age and coercion elements, as well as the type of behavior involved. In this case, some of them even cite age differences of five years or more when the victim is under 12 years and a difference of ten years or more when the child is between 13 and 16 years old, as well as the constant reproduction of the use of force, threat or exploitation of authority (Finkelhor and Hotaling, 1984).

Regarding the incidence, some authors discuss that the ASI as a relevant social and public health problem. This justifies the importance of a data collection about the occurrence, in order to provide knowledge about the true dimension of the phenomenon (Knutson, 1995). According to available epidemiological data on child abuse, the limited definition, that tends to reduce the actual occurrence, is avoided (Kalichman, 1993).

According to estimates by the National Committee for the Prevention of Child Abuse, approximately 150,000 to 200,000 new cases of child sexual abuse are reported each year (Kaplan et al., 1997), with actual occurrence rates higher than estimates, as many abused children are not even recognized or diagnosed (Kaplan and Sadock, 1990).

Despite the low measurement in the number of cases, a study with adult women in San Francisco, conducted by (Russell 1984), demonstrated that even after excluding minor events (victim of exhibitionism without physical contact), $16 \%$ of the sample reported intrafamilial sexual abuse before the age of 18 and $12 \%$ before the age of 14 and extra family sexual abuse with genital sex before the age of 18 was appointed by $31 \%$ of the sample, $20 \%$ before the age of 14 . Among the extra-family sexual abuse before the age of 18 , only $15 \%$ were committed by a stranger. According to a study conducted in the United States, $27 \%$ of women and $16 \%$ of men pointed to at least one experience of sexual abuse in childhood (Finkelhor, et al, 1990).

On the impacts of sexual abuse on children, the consequences are usually divided into physical, emotional, sexual and social, bringing behaviors that are useful for the diagnosis of sexual victimization (Blanchard, 1996), which, according to Furniss (1993) and Knutson (1995), also bring degrees of severity depending on the age of the child at the beginning of sexual abuse: it is not known at what age there is greater harm; the duration of abuse: some evidence suggests that longer duration produces more negative consequences; the degree of violence: use of force by the perpetrator results in more negative consequences both in the short and long term; the age difference between the person who committed the abuse and the victim: the greater the difference, the more serious the consequences; the importance of the relationship between abuser and victim: the greater the proximity and intimacy, the worse the consequences; the absence of protective parental figures and social support: in these cases, psychological damage is aggravated and the degree of secrecy and threats against the child (Kendall-Tackett et al., 1993).

For children and adolescents who are in school, symptoms also include: fear, neurotic disorders, aggression, nightmares, school problems, hyperactivity and regressive behavior, depression, isolation, suicidal behavior, self- 
assault, somatic complaints, illegal acts, escapes, substance abuse, inappropriate sexual behavior (Garfinkel et al., 1992). It is also worth mentioning the feelings of guilt, being one of the most serious emotional effects resulting from abusive interaction, especially if it was incestuous and lasted for a long time. To the feeling of guilt, there is the secondary damage of stigmatization, due to the accusation by parents and family (Furniss, 1993).

There are other feelings experienced by the child who suffers the abuse, such as shame and humiliation, since violence adds to the feeling of shame a content of 'impotence', because the victims cannot find an action that can repair the damage. (Harkot-De-La-Taille, 1999).

One aspect that has been investigated as relevant to the positive prognosis of victims concerns how mothers of abused children deal with the situation. The fact that a mother believes in the report of her son or daughter and takes protective measures may have repercussions on how the victim herself can elaborate the traumatic experience. Since the changes resulting from the discovery of abuse do not affect only the victim interfering in the routine and dynamics of all family members. It is at this moment of crisis that the intervention provides space that offers support, making the person feel safe and realize the positive consequences of their decisions (CFP, 2009).

Despite all of this, several studies indicate that the emotional adjustment of children after abuse and revelation is associated with the way mothers can deal with the situation and the ability to provide emotional support to their children (Leifer, et al., 2001; Paredes, et al., 2001; Pintello and Zuravin, 2001).

Fear of the possible consequences, the desire to have a family and keep it together, the emotional and financial dependence of the partner associated with the punishment of the guardian, can contribute to the notification of violence by the family, especially in situations of intrafamilial sexual abuse, not being performed (Amendola, 2004; Araújo, 2002; Azevedo, 2001; Gonçalves and Ferreira, 2002; Miranda and Yunes, 2007).

\section{Conclusions}

Sexual abuse in children and adolescents is a fact that occurs worldwide and affects all spheres of society. It affects children and adolescents both male and female, with a higher predominance in the latter. These abusive relationships often take place in a family context or by close people.

Blanchard's study (1996) demonstrates that, in this type of relationship, there is an adult in a position of authority and a child who, due to the development phase in which he is, is unable to understand the nature of this sexual contact. According to (Kaplan and Sadock 1990), most cases of sexual abuse involving children are never revealed due to the victim's feelings of guilt, shame, ignorance, and tolerance. Combined with this is the reluctance of some professionals to recognize and report sexual abuse, the insistence of the courts on strict rules of evidence and the fear on the part of families, of their dissolution, if the fact is discovered.

This point includes the importance of new studies and research that seek to analyze more deeply the real social and psychological impact of ASI, considering that in a study conducted by Almeida (2012) investigated evidence data from various therapeutic treatments for sexually abused children. The results of this study demonstrated that there is evidence of reduction of anxiety symptoms in all psychological treatments investigated, but Cognitive Behavioral Therapy was the only psychotherapeutic treatment that demonstrated efficacy when compared to control groups with results maintained after one month of follow-up, in this study the great highlight of Cognitive Behavioral Therapy was concluded.

\section{References}

[1] Amendola, M. F. (2004). Mães que choram: avaliação psicodiagnóstica de mães de crianças vítimas de abuso sexual. In M. C. C. A. Prado (Org.), O mosaico da violência: a perversão na vida cotidiana (pp. 103-169). São Paulo: Vetor

[2] Araújo, M. F. (2002). Violência e abuso sexual na família. Psicologia em Estudo, 7(2), 3-11.

[3] Almeida, V.M. Tratamento psicoterápico para vítimas de abuso sexual infantil: Evidências da literatura internacional. Revista Médica de Minas Gerais [online] 2012.

[4] Azevedo, E. C. (2001). Atendimento psicanalítico a crianças e adolescentes vítimas de abuso sexual. Psicologia: Ciência e Profissão, 21(4), 66-77.

[5] Borges, J.L.; Dell'Aglio, D.D. Abuso Sexual Infantil: Indicadores de Risco e Consequências no Desenvolvimento de Crianças. Interamerican Journal of Psychology. Vol. 42, Num. 3 pp. 528-536, 2008.

[6] Briere, J. \& Elliott, D. M. (2003). Prevalence and psychological sequelae of self-reported childhood physical and sexual abuse in a general population sample of men and women. Child Abuse \& Neglect, 27(10), 1205-1222.

[7] Brandão Junior, P.M.C \& Ramos, P.L. (2010). Abuso sexual: do que se trata? Contribuições da Psicanálise à escuta do sujeito. Psicologia clínica, 22 (1), 71-84.

[8] Blanchard, J. (1996, abril). Sexual exploitation Trabalho apresentado no Congresso Against the Sexual Exploitation of Children, Brasília, Brasil.

[9] Conselho Federal de Psicologia. (2009). Serviço de proteção social a criança e adolescentes vítimas de violência, abuso e exploração sexual e suas famílias: referências para a atuação do psicólogo. Brasília: Conselho Federal de Psicologia.

[10] Cromberg, R. U. (2001). Cena incestuosa: clínica psicanalítica. São Paulo: Casa do Psicólogo.

[11] Dos Santos, M. L. (2007). As falhas nas representações psíquicas, decorrentes de situações traumáticas. Revista do Instituto de Ensino e Pesquisa em Psicoterapia, 9, 3647. 
[12] Elliott, A. N., \& Carnes, C. N. (2001). Reactions of nonoffending parents to the sexual abuse of their child: A review of the literature. Child Maltreatment, 6(4), 314331.

[13] Flores, R. Z., \& Caminha, R. M. (1994). Violência sexual contra crianças e adolescentes: Algumas sugestões para facilitar o diagnóstico correto. Revista de Psiquiatria do Rio Grande do Sul, 16(2), 158-167.

[14] Faiman, C. J. S. (2004). Abuso Sexual em família: a violência do incesto à luz da Psicanálise. São Paulo: Casa do Psicólogo.

[15] Finkelhor, D. (1994). The international epidemiology of child sexual abuse. Child Abuse \& Neglect, 18, 409-417.

[16] Finkelhor, D., Hotaling, G. T. (1984). Sexual abuse in the national incidence study of child abuse and neglect: An appraisal. Child Abuse \& Neglect, 8, 23-33.

[17] Finkelhor, D., Hotaling, G. T., Lewis, I. A., \& Smith, C. (1990). Sexual abuse in a national survey of adult men and women: Prevalence characteristics and risk factors. Child Abuse \& Neglect, 14, 19-28.

[18] Furniss, T. (1993). Abuso sexual da criança: Uma abordagem multidisciplinar - Manejo, terapia e intervençăo legal integrados. Porto Alegre: Artes Médicas

[19] Garfinkel, B. D., Carlson, G. A., \& Weller, E. B. (1992). Transtornos psiquiátricos na infância e adolescência Porto Alegre: Artes Médicas.

[20] Gonçalves, H. S. \& Ferreira, H. L. (2002). A notificação da violência intrafamiliar contra crianças e adolescentes por profissionais da saúde. Cadernos de Saúde Pública, 18(1), 315-319.

[21] Harkot-De-La-Taille, E. (1999). Ensaio semiótico sobre a vergonha. São Paulo: Humanitas.

[22] Jonzon, E., \& Lindblad, F. (2004). Risk factors and protective factors in relation to subjective health among adult female victims of child sexual abuse. Child Abuse \& Neglect, 30(2), 127-143.

[23] Kaplan, H. I., \& Sadock, B. J. (1990). Compêndio de psiquiatria. (2a ed.). Porto Alegre: Artes Médicas.

[24] Kaplan. H. I., Sadock, B. J., \& Grebb, J. A (1997). Compêndio de psiquiatria: Ciências do comportamento e psiquiatria clínica. (7a ed.). Porto Alegre: Artes Médicas.

[25] Kristensen, C. H. (1996). Abuso sexual em meninos. Dissertação de Mestrado não publicada. Curso de Psicologia do Desenvolvimento, Universidade Federal do Rio Grande do Sul, Porto Alegre, RS.

[26] Koller, S. H., \& De Antoni, C. (2004). Violência intrafamiliar: Uma visão ecológica. In S. H. Koller (Ed.), Ecologia do desenvolvimento humano: Pesquisa e intervenção no Brasil (pp. 293-310). São Paulo, SP: Casa do Psicólogo.

[27] Knutson, J. F. (1995). Psychological characteristics of maltreated children: Putative risk factors and consequences. Annual Review of Psychology, 46, 401431.
[28] Kalichman, S. C. (1993). Mandated reporting of suspected child abuse: Ethics, law \& policy. Washington, DC: American Psychological Association.

[29] Kendall-Tackett, K. A., Williams, L. M., \& Finkelhor, D. (1993). Impact of sexual abuse on children: A review and synthesis of recent empirical studies. Psychological Bulletin, 113, 164-180.

[30] Luthar, S.; Cicchetti, D.; Becker, B. (2000): "The Construct of resilience: A critical evaluation and guidelines for future work", Child Development, 71 (3), p. 543-558.

[31] Leifer, M., Kilbane, T., \& Grossman, G. (2001). A three generational study comparing the families of supportive and unsupportive mothers of sexually abused children. Child Maltreatment, 6(4), 353-364.

[32] Mees, L. A. (2001). A psicanálise e o incesto. In L. A, Mees. Abuso sexual, trauma infantil e fantasias femininas (pp.17-39). Porto Alegre: Artes e Ofícios.

[33] MacMillan, H. L., Fleming, J. E., Streiner, D. L., Lin, E., Boyle, M. H., Jamieson, E., et al. (2001). Childhood abuse and lifetime psychopathology in a community sample. American Journal of Psychiatry, 158(11), 18781883.

[34] Miranda, A. T. \& Yunes, M. A. M. (2007). O ato da denúncia de abuso sexual contra crianças e adolescentes no ambiente escolar. In M. L. P. Leal, M. F. P. Leal, \& R. M. C. Libório (Org.), Tráfico de pessoas e violência sexual (pp.167-190). Brasília: VIOLES/SER/Universidade de Brasília

[35] Paredes, M., Leifer, M., \& Kilbane, T. (2001). Maternal variables related to sexually abused children's functioning. Child Abuse \& Neglect, 25, 1159-1176.

[36] Pintello, D. \& Zuravin, S. (2001). Intrafamilial child sexual abuse: Predictors of post disclosure maternal belief and protective action. Child Maltreatment, 6(4), 344-352.

[37] Russell, D. E. H. (1984). The prevalence and seriousness of incestuous abuse: Step-fathers vs. biological fathers. Child Abuse \& Neglect, 8, 15:22.

[38] Sternberg, RJ, \& Grigorenko, EL (2001). Teste de habilidade em diferentes culturas. Em LA Suzuki, JG Ponterotto, \& PJ Meller (Eds.), Manual de avaliação multicultural: aplicações clínicas, psicológicas e educacionais (pp. 335-358). Jossey-Bass / Wiley.

[39] Tyler, K. A. (2002). Social and emotional outcomes of childhood sexual abuse: A review of recent research. Aggression and Violent Behavior, 7(6), 567-589.

[40] Venturini, Fabiola Perri; BAZON, Marina Rezende; BIASOLI-ALVES, Zélia Maria Mendes. Família e violência na ótica de crianças e adolescentes. Estud. pesqui. psicol., Rio de Janeiro, v. 4, n. 1, jun. 2004, p.2033. 